\title{
A cost-benefit analysis of varicella vaccination in Aragón
}

\author{
Guillermo Peña Blasco, Magister ${ }^{a}$ and M. ${ }^{a}$ Jesús Blasco Pérez-Aramendía, M.D. ${ }^{b}$
}

\begin{abstract}
Background. Varicella, a contagious and infectious disease that is usually benign in children, may become complicated among adults and vulnerable children and may even be life-threatening. There are effective vaccines. A retrospective study was conducted about costs and resulting hospitalizations related to this disease in the population of Aragón in the 2004-2014 period. Costs were compared to the expenses that would have been incurred if those people had received the vaccine and also to the expenses of vaccinating the 1-year-old population over the entire period. A cost-benefit analysis was done to assess the economic impact of varicella vaccination.

Method. Data for the 11-year period were provided by the Autonomous Community of Aragón (Spain) and included annual varicella incidence, hospital discharges of varicella cases, costs of primary health care visits and hospitalizations for each year, costs of each workday as per the minimum annual salary and of drugs used). Capitalized costs were estimated and compared to capitalized expenses of vaccination, and a sensitivity analysis was performed.

Results. A benefit-cost ratio of 1.6 was obtained considering that all children who had varicella had been vaccinated and had received a booster dose. A benefit-cost ratio of 1.24 was obtained considering that the vaccine had been administered to every 1-year-old individual at a price of EUR 28.59 per vaccine. Over the 11-year period, $53 \%$ of hospitalizations corresponded to children younger than 5 years old.

Conclusions. Public campaigns for the immunization of children younger than 4 years old with 2 doses lead to cost savings and are cost-effective because the vaccine price results in a benefit-cost ratio greater than 1 . A major reduction is expected in the number of hospitalizations among children aged 3-4 years. Key words: varicella, vaccines, cost-benefit analysis, economy in health care and organizations.
\end{abstract}

http:/ / dx.doi.org/10.5546/ aap.2017.eng.432

To cite: Peña Blasco G, Blasco Pérez-Aramendía J. A cost-benefit analysis of varicella vaccination in Aragón. Arch Argent Pediatr 2017;115(5):432-438.

\section{INTRODUCTION}

Varicella is an infectious, contagious disease caused by varicella-zoster virus which mainly affects children. It is usually benign but $12 \%$ of patients may suffer some sort of complications. It is also highly contagious. Patients should remain in isolation and miss school for several days. In a large population, this also supposes parental absenteeism from work and minor medical expenses for the symptomatic relief of symptoms.

Perinatal varicella, which develops from 5 days before to 2 days after delivery, may be very severe in $30 \%$ of cases. Varicella complications may lead to hospitalizations during childhood, including death, especially among immunocompromised children. In adults, the rate of complications is 25 times higher. ${ }^{1}$ Hospitalization expenses and workplace absenteeism due to varicella imply a large social disbursement. In the United States, it has been estimated that varicella is the most common cause of death attributed to vaccine-preventable diseases.

The varicella vaccine was initially registered for its use exclusively in patients at risk in Europe (1984) and Japan (1986). It was later approved for its general use in South Korea (1988), the United States, Sweden, and Germany (1995). ${ }^{3}$ In Spain, it has been used in hospitals since 1997 and approved for sale at pharmacies in 2005. At present, in Spain, there are two live, attenuated virus (OKA strain) vaccines. ${ }^{1,4}$ In the Autonomous Community of Aragón (1325 million inhabitants in 2014), the vaccine was introduced in the immunization schedule in 2007 for children aged 11 years and a booster dose was introduced in 2009. In Spain, it is 
administered free of charge by the Public Health System. Two vaccine doses provide an overall coverage of $100 \%,{ }^{5}$ and are very well-tolerated. The Spanish Society of Pediatrics' immunization schedule indicates the first dose for 1-year-old infants and a booster dose as of 2-3 years. ${ }^{4}$ In 2016, the varicella vaccine was introduced at a national level in Spain for children aged 15 months old with a booster dose at 3-4 years. ${ }^{6}$

Some countries provide the measles, mumps, rubella and varicella (MMRV) vaccine to infants with the corresponding booster dose. ${ }^{1,7}$

Varicella vaccine critics claim an increase in the incidence of herpes zoster. However, large population-based prospective studies have detected a reduction in the incidence of herpes zoster among vaccinated children compared to those who had wild-type varicella, although additional years of follow-up are required. ${ }^{8}$

In this study, the number of varicella cases in the general population of Aragón over an 11-year period (2004-2014) was assessed. Varicellarelated hospitalizations and the resulting related costs were studied. The objective of this study is to assess varicella vaccination cost-effectiveness, either paid by patients or by the Public Health Administration, provided to the entire 1-year-old population as per the immunization schedule. Our hypothesis is that having varicella is more expensive than receiving the vaccine, even two doses.

\section{MATERIAL AND METHODS}

This was a retrospective study that included the number of varicella cases occurred in Aragón between 2004 and 2014 and hospital discharges registered in the entire community; these data were then analyzed. A cost-benefit analysis was subsequently done to compare varicella-related expenses and vaccine costs.

Incidence data were obtained from the Mandatory Reportable Diseases records of the General Council of Aragón and from primary health care medical records of cases diagnosed with varicella (OMI AP code for Aragón: A72). ${ }^{9}$ Hospital discharge records corresponded to the entire health care network of the Autonomous Community of Aragón (public and private hospitals) with varicella infection as the main diagnosis (data source: basic minimum dataset of the Planning and Insurance Management Division, ICD-9-CM 052, varicella, Aragón) over the 2004-2014 period and for the overall Aragón population.
A retrospective cost-benefit analysis was done, which consisted of comparing investment benefits and capitalized costs and establishing its cost-effectiveness. The benefit-cost ratio (BCR) was used to this end. This index measures, in relative terms, the return on investment, and is calculated as the ratio between the capitalized sum of the benefits and costs, respectively. It is also known as profitability index. A BCR greater than 1 indicates that there is a positive return on the investment whereas a BCR lower than 1 means that the investment is not profitable. The minimum expenses resulting from primary health care visits and hospitalizations per each day in the hospital were estimated. The following were taken into account: cost of a single primary health care pediatric visit (as per the service provision rates for each year according to the Billing Service of Zaragoza Health Sector 3), average minimum expenses for treatment at home (pain killers, antiseptic agents, antipruritic agents: EUR 11.75), and costs of missing a workday for one of the parents as per the inter-professional minimum salary for each year according to the corresponding Official Bulletin of the State. ${ }^{10}$ In relation to hospitalized patients, the cost of each hospitalization day was estimated (as per the service provision rates, including stay and medications, for each year according to the Billing Service of Zaragoza Health Sector 3) multiplied by the mean length of stay for each year, plus the expenses of missing 5 working days for one of the parents or for an adult working patient (as per the inter-professional minimum salary for each year according to the corresponding Official Bulletin of the State). This was because the mean length of stay every year was greater than 4 days, and the Law for the Conciliation of Labor and Family Life allows to miss 5 working days when a dependent family member is hospitalized.

These data were compared to the hypothetical cost that would have been undertaken if every individual affected by varicella every year had received the varicella vaccine at a retail price of EUR 43.63 during routine nurse checkups - at no additional cost - with a booster dose since 2009 . These values were capitalized to the actual price in 2014 at a capitalization factor of 3\%. ${ }^{11}$ Such factor was based on the preference of past over present. The capitalization factor was calculated as follows:

$(1+r)^{\mathrm{t}}$

for each " $\mathrm{t}$ " (study years); " $\mathrm{r}$ " was the rate of 
capitalization. To establish the economic return of implementing the varicella vaccine, the BCR was used.

The costs that would have implied to vaccinate the entire population (100\% coverage) of infants born each year in Aragón from 2004 to 2014 (data from the National Statistics Institute of Spain) with the varicella vaccine up to 2009, and with two doses as of that year, were also calculated at a cost price of EUR 28.59 (General Division of Public Health of the Government of Aragón in 2015). Data were capitalized as per 2014 values, and the BCR was calculated in relation to expenses from 2004 to 2014. Expenses that would have been incurred if the varicella vaccine had not been included in the vaccination schedule were considered returns on the investment, and the money saved by including the vaccine in the schedule was also estimated, whereas the costs of every administered vaccine were considered investment costs. Afterwards, a sensitivity analysis was done with a slight variation in data, for example, changing the capitalization factor from $3 \%$ to $6 \%$ or the vaccine cost from EUR 43.63 to EUR 28.59 to verify robustness of results obtained and causes of variation.

\section{RESULTS}

The number of varicella cases recorded between 2004 and 2014 (Table 1) showed an oscillating pattern that ranged from 8741 cases in 2004 to 4371 in 2013.

TABLE 1. Varicella-related expenses, in Euros, for Aragón over the 2004-2014 period

\begin{tabular}{|c|c|c|c|c|c|c|c|c|c|c|c|}
\hline Year & 2004 & 2005 & 2006 & 2007 & 2008 & 2009 & 2010 & 2011 & 2012 & 2013 & 2014 \\
\hline $\begin{array}{l}\text { Number of } \\
\text { varicella cases }\end{array}$ & 8741 & 6779 & 6183 & 8602 & 5202 & 7561 & 4441 & 5768 & 7087 & 4371 & 7174 \\
\hline $\begin{array}{l}\text { Primary health } \\
\text { care cases }\end{array}$ & 8683 & 6711 & 6126 & 8535 & 5170 & 7519 & 4407 & 5732 & 7042 & 4343 & 7136 \\
\hline Visit expenses & 44.03 & 51.18 & 50.97 & 54.33 & 56.18 & 58.15 & 58.09 & 57.51 & 72.53 & 71.23 & 70.02 \\
\hline $\begin{array}{l}\text { Volumen of } \\
\text { visit expenses }\end{array}$ & 382312.49 & 343468.98 & 312242.22 & 463706.55 & 290450.6 & 437229.85 & 256002.63 & 329647.32 & 510756.26 & 309351.89 & 499662.72 \\
\hline $\begin{array}{l}\text { Expenses for miss } \\
1 \text { workday }\end{array}$ & 15.855 & 17.1 & 18.03 & 19.02 & 20 & 20.8 & 21.11 & 21.38 & 21.38 & 21.51 & 21.51 \\
\hline $\begin{array}{l}\text { Treatment } \\
\text { expenses }\end{array}$ & 11.75 & 11.75 & 11.75 & 11.75 & 11.75 & 11.75 & 11.75 & 11.75 & 11.75 & 11.75 & 11.75 \\
\hline Family expenses & 239694.215 & 193612.35 & 182432.28 & 262621.95 & 164147.5 & 244743.45 & 144814.02 & 189901.16 & 233301.46 & 144448.18 & 237343.36 \\
\hline $\begin{array}{l}\text { Total primary } \\
\text { health care } \\
\text { expenses }\end{array}$ & 622006.705 & 537081.33 & 494674.5 & 726328.5 & 454598.1 & 681973.3 & 400816.65 & 519548.48 & 744057.72 & 453800.07 & 737006.08 \\
\hline $\begin{array}{l}\text { Number of hospit } \\
\text { discharges }\end{array}$ & ital 58 & 68 & 57 & 67 & 32 & 42 & 34 & 36 & 45 & 28 & 38 \\
\hline $\begin{array}{l}\text { Length of stay } \\
\text { in days }\end{array}$ & 7.2 & 7.5 & 5.2 & 6 & 7.9 & 6.6 & 4.8 & 6.9 & 5.6 & 6.6 & 5.2 \\
\hline $\begin{array}{l}\text { Expenses per day } \\
\text { in the hospital }\end{array}$ & 327.6 & 342.02 & 340.6 & 363.09 & 418 & 432 & 443 & 496 & 526 & 556 & 591 \\
\hline $\begin{array}{l}\text { Hospitalization } \\
\text { expenses }\end{array}$ & 136805.76 & 174430.2 & 100953.84 & 145962.18 & 105670.4 & 119750.4 & 72297.6 & 123206.4 & 132552 & 102748.8 & 116781.6 \\
\hline $\begin{array}{l}\text { Volume of expens } \\
\text { for missing } \\
5 \text { workdays }\end{array}$ & $\begin{array}{l}\text { Ises } \\
\qquad 4597.95\end{array}$ & 5814 & 5138.55 & 6371.7 & 3200 & 4368 & 3588.7 & 3848.4 & 4810.5 & 3011.4 & 4086.9 \\
\hline $\begin{array}{l}\text { Total expenses } \\
\text { for hospitalized } \\
\text { patients }\end{array}$ & 141403.71 & 180244.2 & 106092.39 & 152333.88 & 108870.4 & 124118.4 & 75886.3 & 127054.8 & 137362.5 & 105760.2 & 120868.5 \\
\hline Period & 0 & 1 & 2 & 3 & 4 & 5 & 6 & 7 & 8 & 9 & 10 \\
\hline $\begin{array}{l}\text { Volumen of final } \\
\text { expenditure }\end{array}$ & 763410.415 & 717325.53 & 600766.89 & 878662.38 & 563468.5 & 806091.7 & 476702.95 & 646603.28 & 881420.22 & 559560.27 & 857874.58 \\
\hline $\begin{array}{l}\text { Capitalized } \\
\text { volume of final } \\
\text { expenditure }\end{array}$ & 562957.259 & 545333.147 & 470847.061 & 709944.129 & 469353.486 & 692218.371 & 422021.694 & 590137.355 & 829328.285 & 542773.462 & 857874.58 \\
\hline $\begin{array}{l}\text { Total capitalized } \\
\text { volume of } \\
\text { final expenditure }\end{array}$ & & & & & 669278 & & & & & & \\
\hline
\end{tabular}


A total of 505 hospital discharges for varicella infection were recorded in Aragón in the 11-year period (Table 1). There were 67 hospitalizations in 2007, and 32 in 2008. The percentage of hospitalizations by number of varicella cases ranged between $1 \%$ ( 68 hospitalizations out of 6779 cases) in 2005 to $0.52 \%$ (38 hospitalizations out of 7174 cases) in 2014.

When considering hospitalized patients' age, among 505 hospital discharges, $267(53 \%)$ patients were $0-4$ years old; $37(7 \%), 5-14$ years old; 128 (25\%), 15-39 years old; 50 (10\%), 40-64 years old; and $23(5 \%)$ were older than 65 years old.

The mean length of stay throughout the study period was 6.3 days per hospitalized patient, ranging from 4.8 days in 2010 to 7.9 days in 2008 (Table 1). The length of stay ranged from 1 to 35 days. The length of stay was 2-7 days in 361 patients $(71.5 \%)$.
In Table 1, under "total primary health care expenses" it is worth noting that EUR 744057.72 were spent in 2012 versus EUR 400816.65 spent in 2010. Under "total expenses for hospitalized patients" it is observed that the expenses per hospitalization were EUR 180244.2 in 2005 and EUR 75886.3 in 2010. Under "total capitalized volume of final expenditure" it is shown that EUR 6692788.83 were spent over the 11-year period in relation to varicella in Aragón.

In Table 2, under "total capitalized patient vaccination costs" up to 2014, it is observed that the total hypothetical expenses accounted for EUR 4156 649.35, with a BCR of 1.610.

Table 3 shows a total capitalized population vaccination cost of EUR 5380 499.29, with a BCR of 1.244 .

Table 4 shows a sensitivity analysis where it should be noted that the maximum BCR (2.52)

TABLE 2. Costs, in Euros, if varicella patients had been vaccinated, for Aragón

\begin{tabular}{|c|c|c|c|c|c|c|c|c|c|c|c|}
\hline Year & 2004 & 2005 & 2006 & 2007 & 2008 & 2009 & 2010 & 2011 & 2012 & 2013 & 2014 \\
\hline $\begin{array}{l}\text { Number of } \\
\text { varicella cases }\end{array}$ & 8741 & 6779 & 6183 & 8602 & 5202 & 7561 & 4441 & 5768 & 7087 & 4371 & 7174 \\
\hline $\begin{array}{l}\text { Vaccine price } \\
\text { per person }\end{array}$ & 43.63 & 43.63 & 43.63 & 43.63 & 43.63 & $87.26^{*}$ & 87.26 & 87.26 & 87.26 & 87.26 & 87.26 \\
\hline $\begin{array}{l}\text { Patient vaccination } \\
\text { costs }\end{array}$ & 381369.83 & 295767.77 & 269764.29 & 375305.26 & 226963.26 & 659772.86 & 387521.66 & 503315.68 & 618411.62 & 381413.46 & 626003.24 \\
\hline Period & 0 & 1 & 2 & 3 & 4 & 5 & 6 & 7 & 8 & 9 & 10 \\
\hline $\begin{array}{l}\text { Capitalized patient } \\
\text { vaccination costs }\end{array}$ & 281231.31 & 224851.85 & 211425.97 & 303240.21 & 189054.04 & 566569.40 & 343070.14 & 459362.63 & 581863.49 & 369971.06 & 626003.24 \\
\hline $\begin{array}{l}\text { Total capitalized } \\
\text { patient vaccination costs }\end{array}$ & \multicolumn{11}{|c|}{4156643.35} \\
\hline $\mathrm{BCR}^{* *}$ & & & & 1.610 & 14267 & & & & & & \\
\hline
\end{tabular}

* Two vaccine doses are administered as of 2009.

** Benefit-cost ratio.

TABLE 3. Costs. in Euros, for administering the vaccine to the entire 1-year-old population of Aragón

\begin{tabular}{|c|c|c|c|c|c|c|c|c|c|c|c|}
\hline Year & 2004 & 2005 & 2006 & 2007 & 2008 & 2009 & 2010 & 2011 & 2012 & 2013 & 2014 \\
\hline Number of 0 year-olds & 11064.38 & 11533.2971 & 11722.00 & 12392.45 & 12976.73 & 13772.63 & 13129.85 & 12964.39 & 12770.35 & 12007.50 & 11683.50 \\
\hline $\begin{array}{l}\text { Vaccine price } \\
\text { per person }\end{array}$ & 28.59 & 28.59 & 28.59 & 28.59 & 28.59 & $57.18^{*}$ & 57.18 & 57.18 & 57.18 & 57.18 & 57.18 \\
\hline $\begin{array}{l}\text { Population } \\
\text { vaccination costs }\end{array}$ & 316330.75 & 329736.965 & 335132.04 & 354300.24 & 371004.75 & 787518.79 & 750764.61 & 741303.82 & 730208.33 & 686588.88 & 668062.56 \\
\hline Period & 0 & 1 & 2 & 3 & 4 & 5 & 6 & 7 & 8 & 9 & 10 \\
\hline $\begin{array}{l}\text { Capitalized } \\
\text { population } \\
\text { vaccination costs }\end{array}$ & 233269.93 & 250676.28 & 262657.51 & 286268.51 & 309036.57 & 676269.18 & 664646.51 & 676567.98 & 687053.01 & 665991.21 & 668062.56 \\
\hline $\begin{array}{l}\text { Total capitalized } \\
\text { population } \\
\text { vaccination costs }\end{array}$ & & & & & 380499.26 & & & & & & \\
\hline $\mathrm{BCR}^{* *}$ & & & & & 24389736 & & & & & & \\
\hline
\end{tabular}

\footnotetext{
* The booster dose is administered at 3 years old as of 2009.

** Benefit-cost ratio.
} 
for assumption 3 and the minimum BCR (0.795) for assumption 8 ; in both cases, each vaccine has a cost price of EUR 43.63. Once such cost is reduced to EUR 28.59 but keeping the remaining outcome measures the same, the BCR increased to 1.397 (assumption 12).

\section{DISCUSSION}

This study estimates the economic costs of having administered the varicella vaccine to the Aragón population over the past 11 years and shows that immunization in the infant population is cost-effective as long as the Public Health Administration manages to negotiate an adjusted price, as that obtained in 2015. Once hospitalizations for this cause in the Aragón community are analyzed, ${ }^{3}$ it is observed that more than half of cases occurred in children younger than 5 years old; therefore, it is expected that health expenses will decrease following the first years of the immunization campaign as long as coverage is high.

Over the past decade, the greatest number of cases was reported in 2004 and the lowest, in 2013; values were as expected within a sustained oscillating pattern. ${ }^{9}$ In relation to hospitalizations, it is worth noting that these decreased as of the second half of 2008 compared to previous years. In 2005, the vaccine was marketed and parents started to give it to their children, so it is difficult to establish accurate vaccine coverage rates in our records. ${ }^{3}$ Based on our data, the greater percentage of hospitalizations per number of cases $(1 \%)$ was recorded in 2005, which was also the year when the greatest hospitalization expenses were incurred.
This is suggestive of a greater virulence. ${ }^{2}$

The investment necessary to administer the varicella vaccine is cost-effective in all cases, except for assumptions 6 and 8, with the vaccine given to the entire infant population, providing a booster dose as of 2009, and paying a retail price for the vaccine (Table 4). Our study shows that the BCR for administering an initial and a booster dose to the entire infant population with vaccines at a cost price per dose is costeffective. It is also cost-effective if parents assume the responsibility for giving the vaccine at a retail price. The sensitivity analysis showed that assumption 3, with the administration of one dose of the vaccine only to sick individuals at a retail price and assuming a capitalization factor of $6 \%$, is the most cost-effective. This assumption is not consistent with the recommendations of the Spanish Society of Pediatrics, ${ }^{4}$ which suggests that greater effectiveness is achieved with two doses.

The epidemic curve over the past 11 years in Aragón describes an oscillating pattern ${ }^{9}$ and does not show an alteration due to the marketing of the varicella vaccine, that parents may administer on their own. ${ }^{3}$

A reduction in hospital discharges has been recorded in the autonomous communities where infants have been vaccinated. ${ }^{12}$ Our study also observed that hospital discharges reduced to almost a half as of 2008 (with the vaccine already in the market) compared to previous years. It is not possible to assure that is the result of giving the vaccine to infants outside the immunization schedule, which is consistent with the conclusions of Peña-Rey's study. ${ }^{3}$

TABLE 4. Sensitivity analysis for the cost-benefit assessment

\begin{tabular}{lccccc}
\hline Assumption & Number of doses & Vaccine dose costs & Population $^{*}$ & $\mathbf{r}^{* *}$ & BCR $^{* * *}$ \\
\hline 1 & 1 & 43.63 & Patients & $3 \%$ & 2.49430924 \\
2 & 1 & 43.63 & Total population & $3 \%$ & 1.30479171 \\
3 & 1 & 43.63 & Patients & $6 \%$ & 2.51843916 \\
4 & 1 & 43.63 & Total population & $6 \%$ & 1.30457957 \\
5 & $1-2$ & 43.63 & Patients & $3 \%$ & 1.61014267 \\
6 & $1-2$ & 43.63 & Total population & $3 \%$ & 0.81510487 \\
7 & $1-2$ & 43.63 & Patients & $6 \%$ & 1.58105354 \\
8 & $1-2$ & 43.63 & Total population & $6 \%$ & 0.79524677 \\
9 & 1 & 28.59 & Total population & $3 \%$ & 1.991187911 \\
10 & 1 & 28.59 & Total population & $6 \%$ & 2.293184 \\
11 & $1-2$ & 28.59 & Total population & $3 \%$ & 1.24389736 \\
12 & $1-2$ & 28.59 & Total population & $6 \%$ & 1.397881 \\
\hline
\end{tabular}

\footnotetext{
* Patients with varicella or overall 1-year-old population with a booster dose at 3 years old.

${ }^{* *} \mathrm{r}$ : capitalization rate.

*** Benefit-cost ratio.
} 
In our study, it has been observed that it is cost-effective for parents to give the vaccine to their children, even if they buy it at the retail price. It would be even more cost-effective to give 2 vaccine doses to their children (as recommended since 2009) than paying for health care costs and missing workdays.

The study conducted by Pérez-Rubio in Castile and León ${ }^{11}$ shows that immunization with one dose only, not two as recommended by the Spanish Society of Pediatrics ${ }^{4}$ is costeffective. Immunization during adolescence, as demonstrated by Peña-Rey ${ }^{13}$ in their article from 2004, is cost-effective based on the BCR. Other studies have demonstrated the cost-effectiveness of administering the vaccine to children with risk factors. ${ }^{2,7}$

As part of a public immunization strategy, as conducted in Spain and Aragón, the cost of giving the vaccine to the entire population aged 12-15 months with a booster dose at 3 years old would also be cost-effective, as per our data, if paid at a cost price. However, paying the vaccine at a retail price and giving a booster dose may not be cost-effective.

Other studies ${ }^{7}$ have mostly assessed indirect expenses resulting from missing workdays; in our study, we also analyzed health care expenses related to pediatric office visits and hospitalizations, and petty expenses in relation to giving medications at home.

Based on our findings, it is observed that a single vaccine dose results in a higher $B C R$ and is more cost-effective, but population studies show that a booster dose provides long-lasting immunity, for more than 14 years, and in addition prevents severe varicella cases..$^{1-5,7}$ Outbreaks in schools have been observed with a single dose and coverage close to $99 \% .{ }^{5}$ Also with a single dose, the age of varicella onset may be delayed. The bibliography even agrees that this disease is more severe in adults. ${ }^{1,3,7}$ The vaccine effectiveness is very high; public immunization campaigns promoting two doses may help to interrupt varicella transmission in the long term. ${ }^{3,7}$ It has also been seen that cost-effectiveness increases as the cost per dose reduces; the administration of two doses would be essential to optimize vaccination costs (Table 4, assumption 12).

In Europe, the varicella vaccine has been given to infants since 2003 in Sicily and Luxembourg, since 2004 in Germany and Greece, since 2008 in Tuscany and Lithuania, and since 2010 in Cyprus. ${ }^{7}$

In America, official immunization schedules vary depending on the country. In the United States, Canada, and Uruguay, children receive the first dose at 12 months old and a booster dose at 4-6 years. Immunization schedules of Argentina, Brazil, and Mexico include a dose at 15 months. Other countries, like Chile and Peru, have not included the vaccine in their official immunization schedules as of $2016 .^{6}$

It is also evident, according to our results, that hospital discharges for varicella after 4 years of immunization will reduce to a half because 53\% of hospitalizations occur in this age group, as described by the Gil-Prieto ${ }^{14}$ group in 2014 based on communities where infants were vaccinated.

The marketing of other alternatives, such as the MMRV vaccine, ${ }^{1,7}$ already in use in other countries, may mean an improvement in relation to prices and infant discomfort, ${ }^{1,7}$ however, our study has not considered this assumption.

In short, the economic costs of having administered the varicella vaccine in Aragón over the past 11 years may be improved by giving two doses to the infant population as long as the Public Health Administration manages to negotiate the price, as that obtained in 2015, which allows to obtain a BCR greater than 1 . Hospitalizations of children younger than 5 years old will decrease and, therefore, it is expected to observe adequate economic results in a few years following an immunization campaign aimed at the entire infant population with two doses of the varicella vaccine.

\section{Acknowledgments}

We would like to thank the heads of the different institutions for providing the data.

\section{REFERENCES}

1. Salleras L, Salleras M, Soldevila N, et al. Vacunas frente al virus de la varicela zóster. Enferm Infecc Microbiol Clin2015;33(6):411-23.

2. Ruiz Contreras J. Vacunación frente a varicela. Simposium: vacunas, pediatras y necesidades actuales. XXVIII Congreso Nacional de la Asociación Española de Pediatría. Zaragoza, 23-26 de junio de 1999. Zaragoza: An Esp Pediatr; 1999. Pages 82-3.

3. Peña-Rey I, Martínez de Aragón MV, Villaverde Hueso A, et al. Epidemiología de la varicela en España en los períodos pre y post vacunación. Rev Esp Salud Pública 2009;83(5):711-24.

4. Moreno-Pérez D, Álvarez García FJ, Arístegui Fernández $\mathrm{J}$, et al. Calendario de vacunaciones de la Asociación Española de Pediatría: recomendaciones 2015. An Pediatr (Barc) 2015;82(1):44.e1-12.

5. Romera-Guirado FJ, Molina-Salas Y, Pérez-Martín JJ, et al. Efectividad de la vacuna de la varicela en el contexto de brotes escolares en una zona semiurbana. An Pediatr (Barc) 2016;84(1):30-8. 
6. WHO.Vaccine-preventablediseases:monitoringsystem. 2016 global summary. [Accessed on: August 1 ${ }^{\text {st }}, 2016$ ]. Available at: http: / / apps.who.int/immunization_monitoring/ globalsummary.

7. European Centre for Disease Prevention and Control. Varicella vaccination in the European Union Stockholm: ECDC; 2015. [Accessed on: February 22 ${ }^{\text {nd }}, 2017$ ]. Available at: http: / / www.ecdc.europa.eu/en/publications / Publications/Varicella-Guidance-2015.pdf.

8. Su-Ying W, Wen-Liang L. Epidemiology of pediatricherpes zoster after varicella infection: a population-based study. Pediatrics 2015;135(3):e565-71.

9. Dirección General de Salud Pública. Diputación General de Aragón. INFORME CÓDIGOS OMI AP. Aragón. A72. VARICELA- Informe Año 2014. [Accessed on: February 22 $\left.{ }^{\text {nd }}, 2017\right]$. Available at: http://www.aragon. es / estaticos / GobiernoAragon / Departamentos / SanidadBienestarSocialFamilia/Sanidad/Profesionales/13 SaludPublica / 18_Vigilancia_Epidemiologica / 2014_ informe_varicela_OMI_AP_2.pdf.

10. España.MinisteriodeEmpleoySeguridadSocial.RealDecreto 1046/2013, de 27 de diciembre, por el que se fija el salario mínimo interprofesional para 2014. BOE 2013;312:106560-1.
11. Pérez-Rubio A, Castrodeza Sanz JJ, Gil Costa M, et al. Impacto social y económico de la vacunación frente a la varicela a los 15 meses de edad en Castilla y León en 2004. Rev Esp Salud Pública 2008;82(1):101-9.

12. Grupo Evalmed-GRADE. Estudio retrospectivo sobre bases de datos poblacionales para comparar las hospitalizaciones y defunciones por varicela y herpes zóster: 1) En el período 2005-2013 entre las Comunidades Autónomas que vacunan de varicela a los 15-18 meses y las que vacunan a los 12 años; y 2) en estas Comunidades Autónomas entre los períodos 1999-2004 y 2005-2013. Junio 2015. [Accessed on: February $\left.22^{\text {nd }}, 2017\right]$. Available at: http:/ / medicamentos. alames.org/informacion-y-actualidad/investigacion/ estudio-retrospectivo-que-compara-las-hospitalizaciones$y$-defunciones-por-varicela-y-herpes-zoster-1-en-20052013-entre-las-ccaa-que-vacunan-de-varicela-a-los-15-18meses-y-las-que-vacunan-a-los-12/.

13. Peña-Rey I, Pérez-Farinós N, Cortés-García $M$, et al. Coste-efectividad de la vacunación contra la varicela en adolescentes en España. Gac Sanit 2004;18(4):287-94.

14. Gil-Prieto R, WalterS, González-Escalada A, et al.Different vaccination strategies in Spain and its impact on severe varicella and zoster. Vaccine 2014;32(2):277-83. 